\title{
Variability in urine culture reporting by Canadian microbiology laboratories
}

\author{
MiChAEL A NOBLE MD FRCPC, SHIRLEY NIKIFORUK RT
}

MA NOBLE, S NIKIFORUK. Variability in urine culture reporting by Canadian microbiology laboratories. Can J Infect Dis 1996;7(4):247-249.

OBJECTIVE: To determine the ability of microbiology laboratories to perform and to report urine colony counts. DESIGN: Clinical Microbiology Proficiency Testing program participants received stabilized simulated urine samples. Laboratories were asked to perform the appropriate test and report results.

PARTICIPANTS: One hundred and nine clinical microbiology laboratories in British Columbia, Alberta and Nova Scotia. OUTCOME MEASURES: Consistency of reporting was compared with standards for reporting results as described in the SI Manual in Health Care, 2nd edition.

RESULTS: The study demonstrated a wide variation in units used for the reporting of results. Ninety-five (87.2\%) laboratories reported quantitative urine results in a variety of unit styles. Of those laboratories providing results with units, $80(84.2 \%)$ used one of 10 variations of SI reporting styles. Fifteen $(16.8 \%)$ laboratories reported metric units in three different styles. Eleven (10.0\%) laboratories reported semiquantitative values without stating units. The remaining three $(2.8 \%)$ did not respond to the survey.

CONCLUSIONS: Many clinical microbiology laboratories have not adopted a consistent form of SI units for reporting quantitative urine culture results. This lack of consistency could potentially lead to interpretation confusion.

Key Words: Canada, Laboratory standards, Microbiology, Quality Assurance

\section{Variabilité dans les rapports de cultures d'urine remis par les laboratoires canadiens de microbiologie.}

OBJECTIF : Déterminer la capacité des laboratoires de microbiologie à effectuer la numération des colonies bactériennes dans l'urine et d'en faire rapport.

MODÈLE : Les participants à un programme d'évaluation du rendement à l'intention des laboratoires de microbiologie clinique ont reçu des échantillons d'urine simulés stabilisés. On a invité les laboratoires à effectuer les analyses appropriées et à remettre un rapport des résultats.

PARTICIPANTS : Cent neuf laboratoires de microbiologie clinique en Colombie-Britannique, en Alberta et en NouvelleÉcosse.

MESURES PARAMÉTRIQUES : La cohésion des rapports a été comparée aux normes décrites dans la deuxième édition du SI Manual in Health Care.

RÉSULTATS : L'étude a révélé une grande variation quant aux unités utilisées dans les rapports.

Quatre-vingt-quinze $(87,2 \%)$ laboratoires ont présenté des résultats quantitatifs, représentés par diverses unités. Parmi ces laboratoires, offrant des résultats en unités, $80(84,2 \%)$ utilisaient l'une des dix variations du système SI. Quinze $(16,8 \%)$ laboratoires ont présenté des unités métriques sous trois modes différents, $11(10,0 \%)$ laboratoires ont présenté des valeurs semi-quantitatives, sans unités. Les trois autres $(2,8 \%)$ n’ont pas répondu au sondage.

CONCLUSIONS : De nombreux laboratoires de microbiologie clinique n'ont pas adopté une forme cohérente d'unités SI pour émettre leurs rapports des résultats quantitatifs des cultures d'urine. Ce manque de cohésion peut nuire à l'interprétation des résultats.

Clinical Microbiology Proficiency Testing, Department of Pathology and Laboratory Medicine, University of British Columbia, Vancouver, British Columbia

Correspondence and reprints: Dr MA Noble, Microbiology Laboratory, Vancouver General Hospital, 855 West 12th Street, Vancouver, British Columbia V5Z 1M9. Telephone 604-875-4630, fax 604-875-4100, e-mail: mnoble@unixg.ubc.ca

Received for publication August 1, 1995. Accepted February 29, 1996 
$\mathrm{T}$ he essential communication of clinical laboratories is the timely report of clinically useful information derived from clinically relevant samples. Internally, laboratories determine a style for reporting results; however, where possible the style is based on community standards. In 1981, a consensus was developed within the Canadian health care community to standardize the reporting of clinical laboratories using SI units. The following reports the results of a proficiency testing survey performed in multiple regions across Canada 14 years after the introduction and acceptance of SI units as the standard. It examined the degree of acceptance of SI units by clinical microbiology laboratories.

\section{MATERIALS AND METHODS}

The survey was developed by the Clinical Microbiology Proficiency Testing program. All laboratories routinely participating in the program received a liquid sample which simulated a stabilized urine sample. The sample was $1 \mathrm{~mL}$ of Meuller Hinton broth containing Enterobacter aerogenes in a concentration of 35,000 bacteria/mL. The concentration of bacteria was stabilized by boric acid $(18 \mathrm{mg} / \mathrm{mL})$ and sodium formate $(9$ $\mathrm{mg} / \mathrm{mL}$ ). This technique was originally developed to standardize the proficiency testing of drinking water laboratories (1). Before being sent, the material was shown to be stable in a variety of atmospheres over a range of $\pm 20 \%$ for up to seven days when maintained at room temperature.

Each laboratory was asked to process the sample as a typical urine culture and report the colony count, bacterial identity and susceptibility of the contents. Laboratories that did not provide a colony count were contacted by telephone and the results recorded.

\section{RESULTS}

In total 109 laboratories received samples. Of the 109 laboratories, 106 (97.2\%) provided a colony count result. Colony counts ranged from $1 \times 10^{6} / \mathrm{L}$ to greater than $100 \times 10^{6} / \mathrm{L}$. For those laboratories supplying an actual value, the mean, median and modal responses were $30.2 \times 10^{6} / \mathrm{L}, 25 \times 10^{6} / \mathrm{L}$ and $30 \times 10^{6} / \mathrm{L}$, respectively, all well within the expected range. The distribution, however, was skewed by a cluster of laboratories that reported results greater than $100 \times 10^{6} / \mathrm{L}$.

Some variation in quantification can result from bacterial growth or loss during transit, however, no significant correlation was observed between the recorded date of receipt or the distance travelled and the reporting of an aberrant high result. The 18 laboratories reporting a bacterial concentration higher than $100 \times 10^{6} / \mathrm{L}$ were located in one region of one province, routinely received urine specimens on dip slides only and, as such, did not normally perform quantitative counts.

of note was the wide assortment of units used to express colony count. Among the 106 responses, there were 13 different variations in units (Table 1). Eighty laboratories reported units in a variety of variations of SI units (number of bacte$\mathrm{ria} / \mathrm{L}$ of urine), while 15 reported using variations of metric units (number of bacteria/mL of urine). The variations were broadened by reports incorporating a spectrum of exponential terms including $\times 10^{6}, \times 10^{7}, \times 10^{8}$ and $\times 10^{9}$. Also used were
TABLE 1

Units used to express colony counts

\begin{tabular}{|c|c|c|}
\hline Type of units & $\begin{array}{l}\text { Number of } \\
\text { laboratories }\end{array}$ & Units used \\
\hline SI (number/L) & 80 & $\begin{array}{c}\mathrm{M} / \mathrm{LM} \\
\mathrm{cfu} / \mathrm{L} \\
\text { Mega } \mathrm{cfu} / \mathrm{L} \\
\text { number } / \mathrm{L} \\
\text { number } \times 10^{6} / \mathrm{L} \\
\text { number } \times 10^{7} / \mathrm{L} \\
\text { number } \times 10^{8} / \mathrm{L} \\
\text { number } \times 10^{9} / \mathrm{L} \\
\text { range } / \mathrm{L} \\
\text { range } \times 10^{6} / \mathrm{L}\end{array}$ \\
\hline $\begin{array}{l}\text { Metric } \\
\quad(\text { number } / \mathrm{mL})\end{array}$ & 15 & $\begin{array}{c}\text { number } / \mathrm{mL} \\
\text { number } \times 10^{5} / \mathrm{mL} \\
\text { range } / \mathrm{mL}\end{array}$ \\
\hline No units & 11 & - \\
\hline
\end{tabular}

the metric prefix notations including $\mathrm{M} / \mathrm{L}$ or $\mathrm{M} \mathrm{cfu} / \mathrm{L}$ or Mega $\mathrm{cfu} / \mathrm{L}$.

The remaining 11 laboratories reported the presence of bacteria, properly identified, but did not report any units. These laboratories reported semiquantitative values $\left(1^{+}-4^{+}\right)$ without reporting any units. Routinely, these laboratories only process urine samples submitted in dip slides. While dip slides can be reported using conventional units, it is recognized that these reported values are an estimate only.

of the variations reported, it was noted that three laboratories used the unit 'number $\times 10^{9} \mathrm{cfu} / \mathrm{L}$ ', which by definition would be out by at least a factor of 10 and perhaps as high as 1000 .

\section{DISCUSSION}

SI units were introduced in Canadian laboratories in 1982 to be consistent with the Conference Générale des Poids et Measures of 1960 (2). The SI Manual in Health Care (second edition) recommended converting the reporting of quantitative urine bacteriology from the metric standard to the SI standard (ie, number of bacteria/L). Because of the work of a large number of representative organizations, including the Intersociety Council for Laboratory Medicine in Canada and the SI Manual in Health Care subcommittee, the conversion to SI unit reporting should have occurred throughout Canada's health care sector. The results of this study, however, showed that the conversion to SI units in microbiology is not complete. There may be many reasons for this. The urinary tract infection and urine colony count literature is replete with the unit 'colonies/mL/'. The metric form tends to be used consistently in American publications and texts $(3,4)$. Finally, the application of litres as a measure of volume for urine specimens does not always seem to be logical or appropriate from a clinical perspective. This lack of clinical perspective may have been a factor in why some laboratories miscalculated the appropriate exponential terms expression, thus resulting in the reporting of $10^{9} \mathrm{cfu} / \mathrm{L}$.

For the purposes of proficiency testing and reporting, the 
variation in units used for reporting is of interest because it demonstrates an area for which improvement in consistency can be recommended. More important, however, is the confusion the different units may cause. If a physician receives reports from various laboratories, and the variation in reporting of units results in confusion when interpreting test results, this could create a serious problem.

\section{REFERENCES}

1. Noble MA. Development of a liquid sample suitable for national proficiency testing for water bacteriology. Conjoint Meeting on Infectious Diseases. Quebec City, December 2-5, 1991.

2. Sub-Committee Sector 9.10. Health and Welfare, Metric Commission of Canada.The SI Manual In Health Care, 2nd edn. Ottawa: Health and Welfarem Metric Commission of Canada, 1982 .
In conclusion, after 12 years, the strategy promoting the adoption of SI units in all Canadian laboratories has not been completely implemented, at least with respect to microbiology's reporting of urine colony counts. The resulting mix of units could potentially result in confusion when interpreting results. Recognition of this outcome may be important when implementing other national guidelines.

3. Pezzlo M. Urine culture procedure. In: Isenberg HD, ed. Clinical Microbiology Procedures Handbook. Washington: American Society for Microbiology, 1992:1.17.1-15

4. Forbes BA, Granato PA. Processing specimens for bacteria. In: Murray PR, Baron EJ, Pfaller MA, Tenover TC, Yolken RH, eds. Manual of Clinical Microbiology, 6th edn. Washington: American Society for Microbiology, 1995:265-81. 


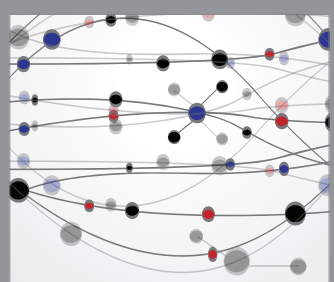

The Scientific World Journal
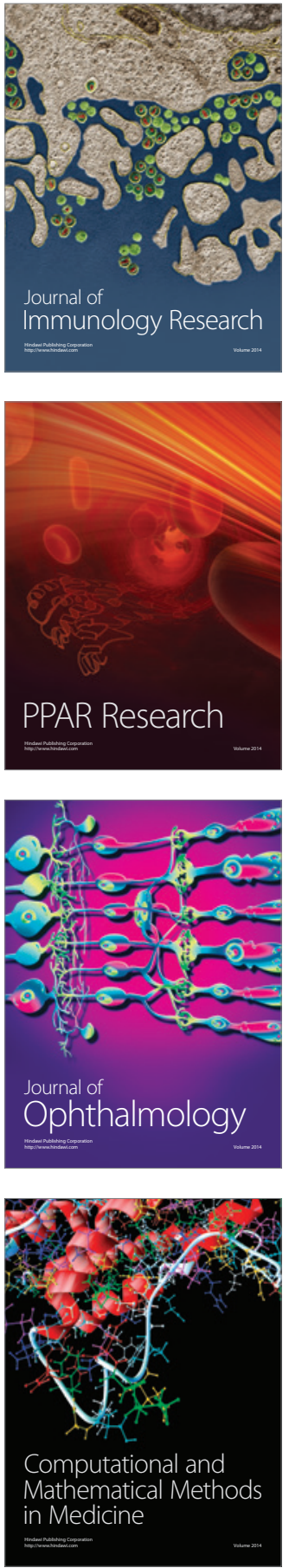

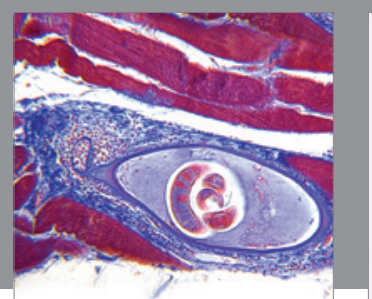

Gastroenterology Research and Practice

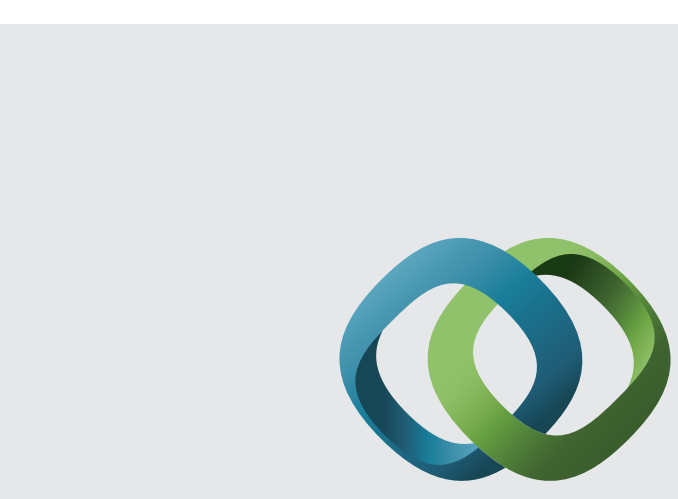

\section{Hindawi}

Submit your manuscripts at

http://www.hindawi.com
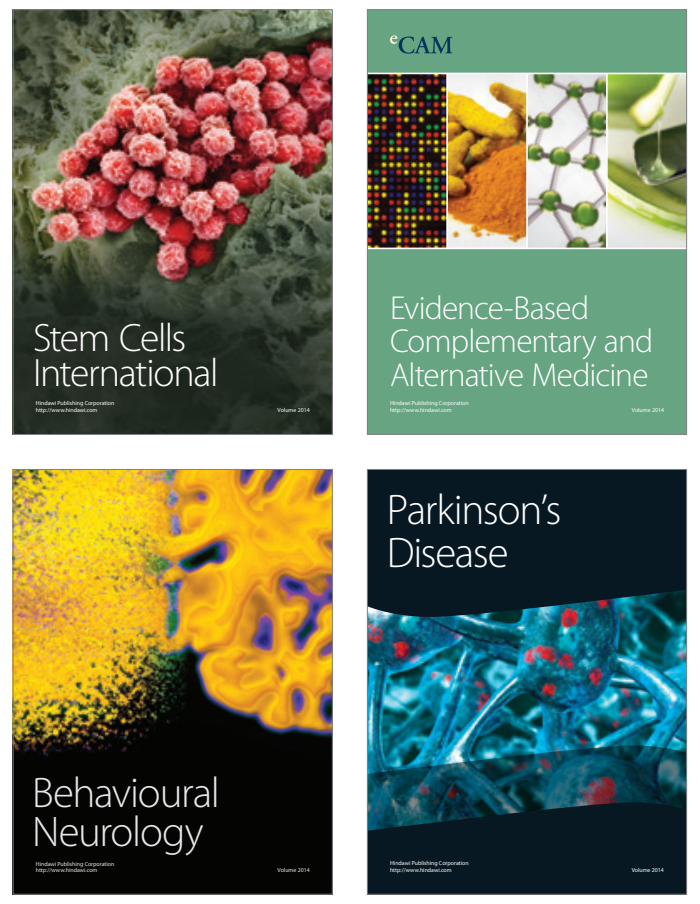
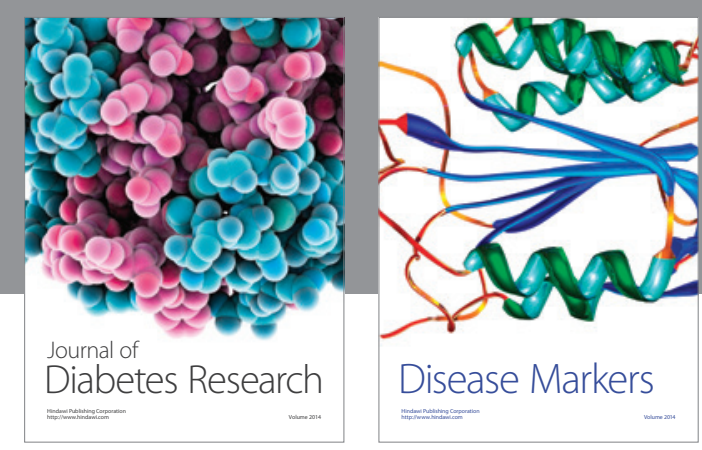

Disease Markers
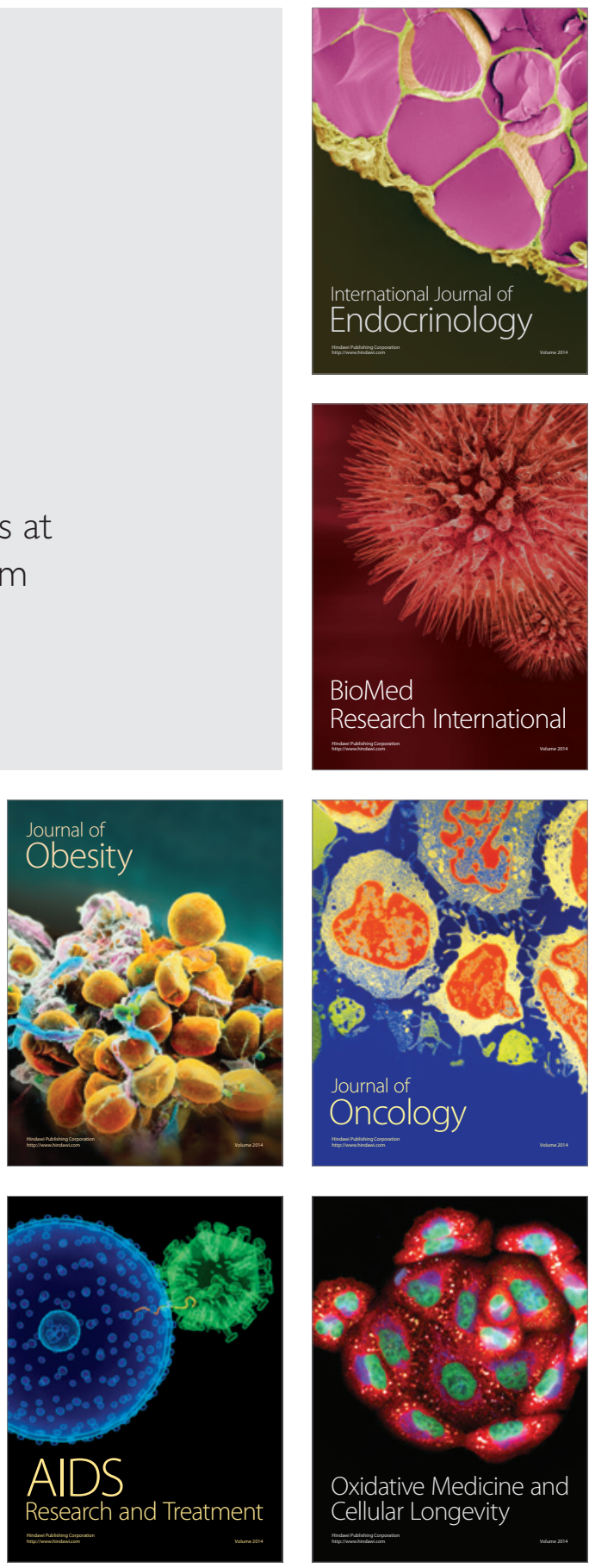